\title{
有機化合物のマススペクトル
}

\section{McLafferty 転位を中心にして}

\section{佐々木慎一・板垣又丕*}

Mass Spectrometry in Organic Chemistry.

McLafferty Rearrangement

はじめに

質量分析法は有機化学 の分野では石油化学の方 面で組成分析等に利用さ れていたにすぎなかった が, 全ガラス導入系, 直 接導入法, 高分解能マス スペクトロメーターの開 発など分析機器自体の目 ざましい改良, 進歩と共 に試料が微量 $(r$ 単位) で測定できるといら特性 とあいまって，現在では 分子量の大きい(たとえ ば 1000 程度のものも) 有機化合物の構造解析に 利用されるようになっ た。したがって発表され る報告の数も急速に増加 し,また物理 定数とし て, 核磁気共鳴スペクト ルの $\tau$ 值, 赤外線吸収ス ペクトルの波数と共に文 献に記载されるようにさ えなってきた。

* 東北大学理学部 (宮 城県仙台市片平丁)

* Department of Chemistry, Tohoku University (Katahira-cho, Sendai, Miyagi-ken, Japan)
Shin-ichi SASAKI* and Yasuhiro ITAGAKI*

a)
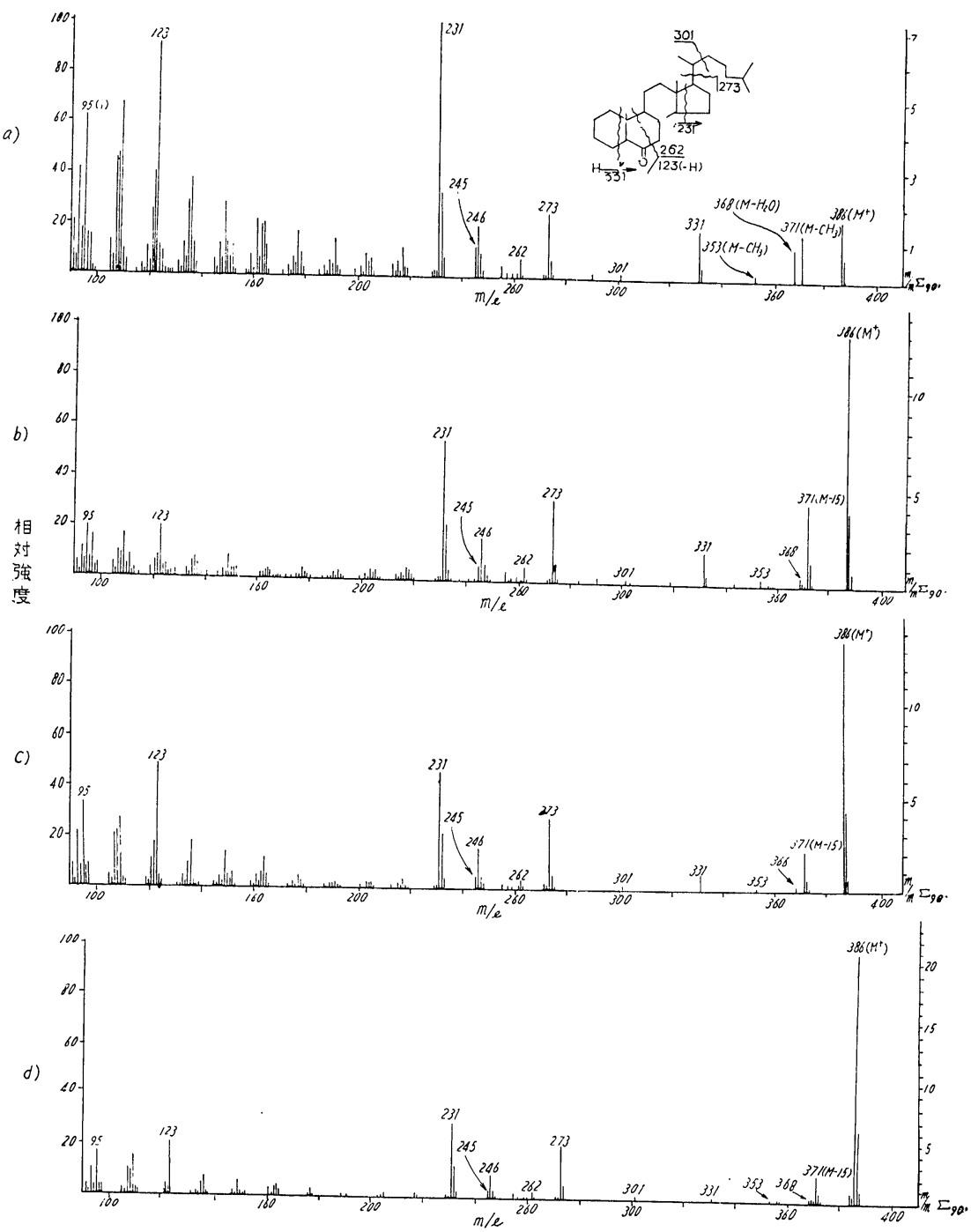

図 1 cholestan-6-one のマススペクトル

a) CEC 21-103C 全ガラス導入系間接導入法 $200^{\circ} \mathrm{C}$ で吩化 (イオン化室温度 $250^{\circ} \mathrm{C}$ )

b) CEC $21-103 \mathrm{C}$ 直接莩入法 (

c) AEI MS-9 直接導入法 (イオン化室温度 $250^{\circ} \mathrm{C}$ )

d) Atlas $\mathrm{CH}-4$ 直接導入法 ( $\mathrm{TO} 4$ イオン源, $70^{\circ} \mathrm{C}$ ) 
しかしながら奏際にわが国の有機化学者が質量分析計 を利用し始めてからの歴史が浅いこと，また従来有機化 学者が取り报ってきた化学的手法と性質を全く異にして いること，さらに測定条件および使用した質量分析計の 機種によって得られるスペクトル図には相当の違いがみ られることなど1 から（図 1),多くの人々にとって必ず しも身近かな分析法でないことは否めない事実であり， 解析を行なうさいにも開裂の機構に多くの可能性が考え られ，ある場合にはまったく推測の域を出ないこともあ り，実際のスペクトルを手にして相当困惑を感じられる 人の少なくないのが現状ではあるまいか。

質量分析の本質的な問題，たとえば熱電子線で衝撃さ れた時の試料の状態，イオン化され，励起状態にある分 子がさらに安定なフラグメントイオン，中性分子，ラジ カル等へ開裂を起こして行くさいの機構等本質的要因に ついては深く研究が掘さげられて扔り，一方応用方面で はスペクトルにあらわれる全組成の高分解能マススペク トロメーターによる決定などの試みが多くの人々によっ てなされている。したがって質量分析法は単なる分子量 決定, 分析のための利用という時期を過ぎ，いまや未知 物 (特に天然物) の構造解明に普通に利用しうるほど確 度の高い手段になってきているといえよら。ここでは主 に電子衝慗を受けた有機化合物が開裂を起こして行く場 合の機構とそれを支配する要因および構造解析に対する 種々の応用についてのべてみたいと思う。

aliphatic hydrocarbons alkylbenzenes

olefins

aliphatic alcohols

steroids

vinyl ethers

aliphatic ethers

aromatic esters and acids

quinones and polycyclic ketones

phenols and aromatic alcohols

furanes.

aliphatic amines

aliphatic amides

amino esters

aliphatic nitriles

fluorocarbons

halogenated compounds

\section{I. 歴史}

マススペクトルは 1800 年代の末にすでに研究が開 始 され，J.J. Thomson はこれによって1912 年にネオン の 2 個の同位体の存在を認め, 続いて F.W. Aston, A.

J. Dempster らが研究を行なっている。一方機器の改良. については, K.T. Bainbridge, W. Bleakney, H.D. Smyth そして特に A.O. Nier らの功績が大きい。しか. し最初マススペクトロメーターは同位体の存在比の決定 等に利用されたにすぎず，実際に有機化合物を対象とし， て利用されはじめたのは 1940 年に入ってからであり, しかも石油化学において炭化水素のような液体化合物の. 分析に使われていたにすぎない。その後機器の進歩, 特 に導入部の改良にともない複雑な有機化合物，ステロイ ド，アルカロイド，テルペン,アミノ酸,糖などにもこれ， が利用されるようになり，有機化学者がこの分野に新し い可能性を開拓しはじめたのである。この有機化合物質 量分析の黎明期ともいうべき時期は大ざっぱにいって二 つに大別できる。すなわち 1950 年から 1959 年頃までに Beynon $^{2)}$,Stenhagen, Ryhage ${ }^{3,4)}$, Meyerson $^{5)} さ ら に \mathrm{Mc}$ Lafferty $^{6)}$ らは簡単な 1 個の官能基だけを有する一連の 系列の化合物のマススペクトルを測定し, 開裂機構の一 般則に関する研究をおこなった。この間に未知物質特に. 有機天然物の構造決定に必要な諸経験則が提出された が，依然として化合物の同定にマススペクトルを用いる，
マススペクトルの $\left(\begin{array}{c}\text { 1) 機器部門 } \\ \text { 2：分析部門 }\end{array}\right.$
a）単収㪘，二重収㪘型マススペクトロメーター等スペクトロメーターの開発
b）付瀊する導入系, 記録計の開発
c）特殊な目的のための装置，出現電圧の測定等
関連する部門
a) 無機化学, 地球化学
b) 有機化学 (石油化学, 定量分析)
4) 有機構造部門
ermodynamics, Quasi-equilibrium Theory イオンー分子反応等
5）有機反応部門 ラベル化合物による生合成, 反応機構の決定, 光化学, 放射化学, 熱化学への応用
(6) 合 成 部 門 マススペクトロメトリーのために新らたに生じた特殊部門で, 重水秦化体をはじ
未知物 (天然物等) の構造決定, フラグメンテーション，關裂機構の研究，立体構 等の推定

aromatic ethers acetals

aliphatic aldehydes aromatic aldehydes cyclic ketones aliphatic esters (dibasic) nitro alkanes

nitro benzenes alkyl pyridines alkyl pysazines alkyl indoles alkyl mercaptans dialkyl sulfides thiophenes silylethers aliphatic ketones

aliphatic esters (alkyl-substituted)

aliphatic esters (unsaturated)

aliphatic esters(hydroxy-, oxo-, epoxy-)

lactones 
趿いった分析的色彩の潾いものであった。この時期にな された一連の化合物の系列は 911 ページに示すものであ $3^{8 a)}$ 。

続いての 1960 年代に入ると微量にしか得られないア ルカロイドの構造決定に示されるような K. Biemann? の研究, C. Djerassi, H. Budzikiewicz, D.H. Williams ‘a，b）らにみられるような新しい手法が展 開されてきた 時期であり，その目的も有機化学的な面にしぼってみて も以下のように相当多岐にわたっていることが理解され よう。

\section{II. イオンの開裂亡転位}

1. 一般に有機化合物がイオン化室内で熱電子線の衝 慗を受けるとき，その電子流のエネルギーがその化合物 のイオン化ポテンシャルと同じ程度のものであれば，単 化分子イオンを与えるに過ぎないが，加えるエネルギー 老漸次増してゆけば分子イオンは解離エネルギー以上の エネルギーを有するようになり，開裂をおこしてフラグ メントイオンを生成する。

なおこれらのフラグメントイオンがさらに余分なエネ ルギーを有している場合にはつぎつぎと開裂をくり返 し，小さなフラグメントイオンを生成して安定化する。こ の場合熱電子から有機化合物任対して移るエネルギ一量 は正確には知られていないが，恐らく衝揧のさいに気化 した化合物分子に電子が命中したか，むしくはかすめ去 ったかという程度の違いによって移るエネルギー量は違 ってくるといわれている10)。いずれにせよ普通の化合物 においては衝撃する熱電子のエネルギーを変化させると 図 2 に示されるように熱電子のエネルギーが $50 \mathrm{eV}$ 以

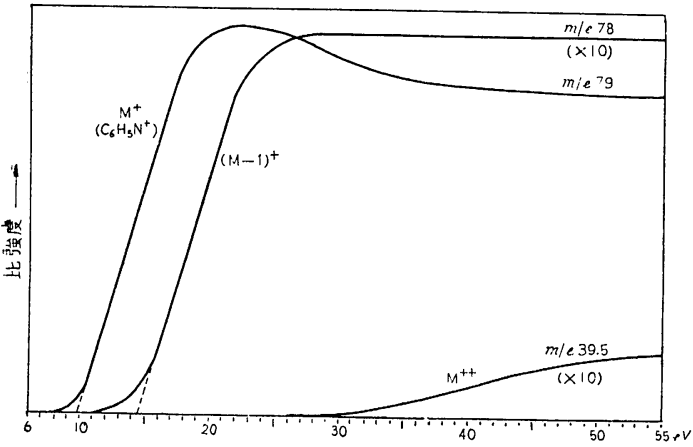

図 2 ピリジンの分子イオン $\left(\mathrm{M}^{+}\right)$と $\mathrm{M}-1$ イオンの 比強度と電子エネルギーとの関係

上になると各イオンの相詨強度は熱電子のエネルギーの 差をあまり受けず，ほとんど一定となり，再現性のある スペクトルが得られるようになる ${ }^{\mathrm{bb})}$ 。そのため有機化 合物の構造解析には主としてこの程度のエネルギーをも つ熱電子が用いられている。開裂にあたっては正イオ
ン，負イオン，中性分子，ラジカルが生成し，このうち 正イオンだけがリペラー電圧によってイオン化室出口に 押し出され，さらに加速されて磁界に入ってゆく，ここ で正イオン群のうち次の条件を満足させるものだけが $\mathrm{r}$ なる偏向半径で偏向されてコレクターに収束される。

$$
\begin{aligned}
& \mathrm{m} / \mathrm{e}=4.82 \times 10^{-5} \times \stackrel{\mathrm{r}^{2} \mathrm{H}^{2}}{\mathrm{~V}} \\
& \mathrm{~m} \text { : 正イオンの啠量 } \mathrm{r} \text { : 分析管の半柊 }
\end{aligned}
$$

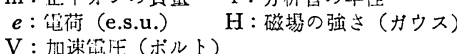

それよりも $\mathrm{m} / e$ (質量数) の大きいイオンは外側へ，小 さいイオンは内側へ分散する。一方陰イオンの測定は困 難であり，正イオンの $1 / 10^{4}$ 程度の量しか生成せず主に Von Ardenne ${ }^{11)}$ が研究を行なっているほか C. Djerassi 12）が芳香環を有する化合物について正イオンと対比さ せて報告を行なっている程度で分子量の決定にきわめて 便利な場合があることが知られているが，有機化合物を 対象とした本格的な研究はいまだになされておらず今後 の研究が待たれる。

2. 開裂をおこすまでの分子の状態 化学反応にお いては試薬がある特定の官能基もしくは結合部を攻揧す るわけであるが，マススペクトロメーター中において熱 電子が分子のある特定の位置を街揧するというようなこ とはない。化合物の分子に比して十分無視しうるほどの 大きさしかない熱電子は分子のいかなる場所をも通り抜 けらるために，結合性，非結合性電子の区別なしに電子 を吒き出し，異なった励起された状態の分子を与える。 しかしこの電子が吒き出されたところで結合や開裂が起 こるのではなく, $10^{-14} \mathrm{sec}$ 程度の速さで, 開裂が起こる前 に電子の再配列がなされる。しかもイオン化の過程で結 合や開裂の間にはかなりの時間 $\left(10^{-6} \mathrm{sec}\right.$ な゙ $)$ があって 分子イオンを構成する原子核の位置も変りうる。こうし て電子衝撃によって分子に与えられたエネルギーのうち イオン化ポテンシャル以上のエネルギーは分子全体のい たるところに均一に分配され各結合を活性化させる ${ }^{133}$ 。 しかしこの考えは大きい分子に抢いては開裂が起こる前 に分子内のある一部にしかもエネルギーが行きわたらな い，すなわち衝撃部分に励起エネルギーが局在化し，そ の部分が分子イオンから “抜け落ちる”とする gurév ${ }^{14}$ 理論とは背反し，いまだ十分な結論が出されているとは いえないがメタステーブルピークの位置を決定する式 $\mathrm{m}^{*}=\frac{\mathrm{m}_{2}{ }^{2}}{\mathrm{~m}_{1}}$ は上の考え方から導き出され非常に良く説明 されることから現在最も信頼されているものである。

このようにして活性化されたもののうちあるものは単 分子分解反応に扔ける活性錯合体 (activated complex あるいは遷移状態 transition state）に相当し，この活 
性化エネルギーの小さい結合ほど開裂しやすい。このよ うにして生成したフラグメントイオンの相対強度は, 活 性化エネルギ一が小さければ増加し，さらにできたイオ ンそのものが安定かどうかという2つの要素に支配され る。例えば置換基を有さない芳香化合物では $\pi$-電子の ため比較的低いエネルギーでイオン化され，生じたカチ オンは $\pi$-電子によって共鳴安定化され，この分子イオ ンがさらに開裂を起こすにはより高いエネルギーを必要 とする。このため芳香環を有するような化合物において は分子イオンの生成が非常に多く, フラグメントイオン をあまり多く生じない。

一方飽和の炭化水素においては $\sigma$-電子が吒き出され る。この $\sigma$-電子は $\pi$-電子よりも安定で, イオン化には それだけよけいエネルギーを必要とするが分子イオンに おいて正電荷は共鳴などにより安定化されることがな い。従って分子イオンは小さくなりフラグメントイオン の生成量が増大する。

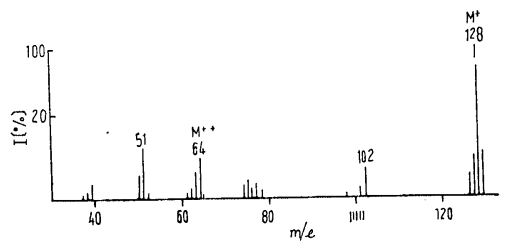

図 3 naphthalene のマススペクトル

3. ピークの種類 多原子分子 $\mathrm{ABCD}$ は上に述べ た機構で開裂してゆくがこれを模式的に示すとつぎのよ うになる ${ }^{\mathrm{sc})}$

i. 分子イオン 分子から電子が 1 個吒き出されて生 成するイオンで一般には $\mathrm{M}^{+}$で表わす。 $\mathrm{M}^{+}$の質量数は この分子の分子量に相当するが高分解能マススペクトル メーターを用いれば分子量だけでなく分子式をも知るこ とができるので最も重要なピークである。しかしこのも のの強度は試料の性誓によって相当変化し, 全然検出で きない場合もある。また非常にまれな場合であるが (4)

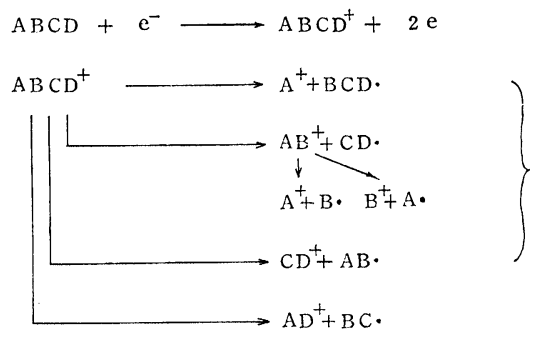

(1)

(3)

$\mathrm{ABCD}^{+}+\mathrm{ABCD} \longrightarrow[\mathrm{ABCD} \cdot \mathrm{ABCD}]^{+} \rightarrow \mathrm{ABCDA}^{+}+\mathrm{BCD}^{-}$

(4)

の機構によって生成したイオンによって実際の分子量よ. り大きな質量数を与えることもあるので注意を必要とす る ${ }^{8 \mathrm{c})}$ 。また分子イオンは $10^{-5} \mathrm{sec}$ 程度以上の寿命がない とイオンコレクターに到達する前に分解してしまって分 子イオンとしては観測されないことになる。

ii. 学純開裂イオン（Fragment ion）分子イオン の結合の一つが単純開裂したイオンで，フラグメントイ オンという。分子イオンから多くの競争的開裂反忘によ って種々のフラグメントイオンを生成する。Biemann: はこの開裂機構を 8 種類の型に分類している ${ }^{\mathrm{d} \mathrm{d})}$ 。そし てこの場合のイオン強度は生成したイオンの安定性によ るむのであり McLafferty は偶数電子を有するイオンが. 奇数電子を有するラジカル・イオンよりも安定であると いっている ${ }^{15)} 。$

単純開裂機構

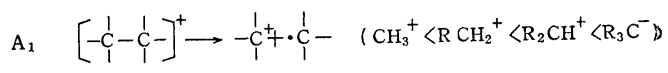

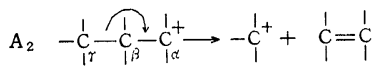

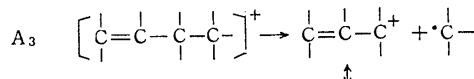
$+\underset{1}{\mathrm{C}}-\stackrel{1}{\mathrm{C}}=\frac{1}{\mathrm{C}}$

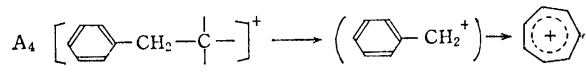

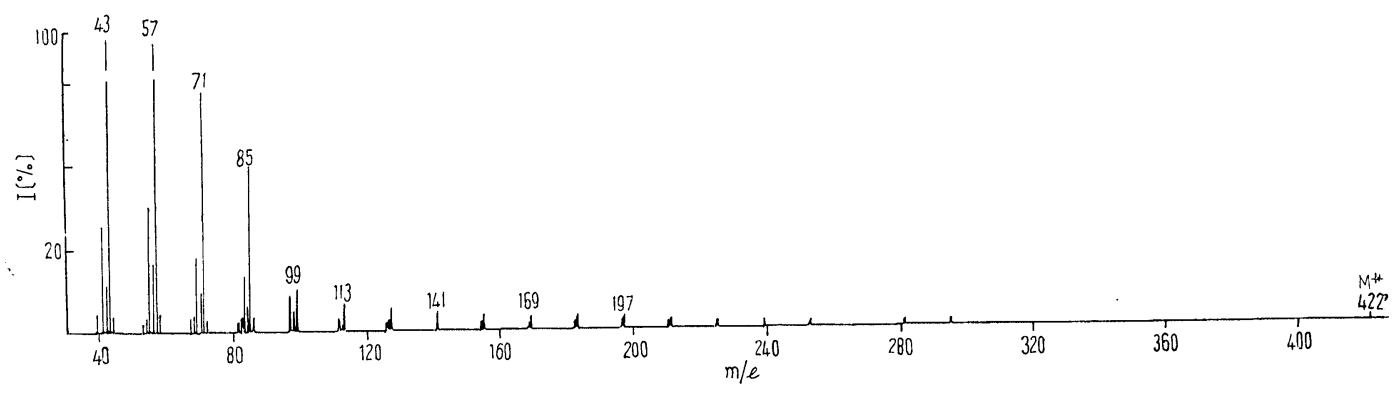

図 $4 n$-triacontane $\mathrm{H}_{3} \mathrm{C}-\left(\mathrm{CH}_{2}\right)_{28}-\mathrm{CH}_{8}$ のマススペクトル 

$A_{5}\left[\begin{array}{c}1 \\ -\mathrm{C} \\ 1\end{array}-\mathrm{X}\right]^{+} \rightarrow-\stackrel{1}{C}^{+}+\mathrm{X}$
( $\mathrm{X}=$ halogen, $\mathrm{OR}, \mathrm{SR}, \mathrm{NR}_{2}, \mathrm{R}=\mathrm{H}$ or alkyh)

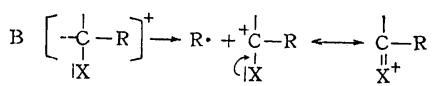
$\mathrm{C}\left[\begin{array}{c}\mathrm{R}-\mathrm{C}-\mathrm{R} \\ \stackrel{\|}{\mathrm{O} \mid}\end{array}\right]^{+} \rightarrow \mathrm{R}-\stackrel{+}{\mathrm{C}} \stackrel{\varrho}{=} \underline{\mathrm{O}} \leftrightarrow \mathrm{R}-\mathrm{C} \equiv \mathrm{O}^{+}$

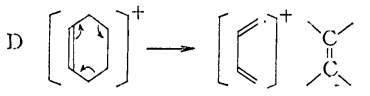

iii. 転位イオン (rearrangement ion) マスス ペクトルにみられる上記の単純開裂イオンだけでは説明 できず原子もしくは原子団の転位を考えなければならな いピークがある。この場合炭化水素のように各結合のエ ネルギー差が小さいときは各所で多数の転位がおこる。 このような場合を McLafferty は無差別転位 (random-

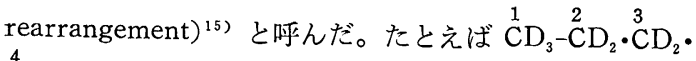
$\stackrel{4}{\mathrm{C}} \mathrm{H}_{3}$ のスペクトルを測定すると

$\mathrm{C}_{3} \mathrm{HD}_{6}(3.1 \%), \mathrm{C}_{3} \mathrm{H}_{2} \mathrm{D}_{2}(3.8 \%) \mathrm{C}_{2} \mathrm{HD}_{4}(1.1 \%)$

$\mathrm{C}_{3} \mathrm{D}_{7}(20 \%), \mathrm{C}_{2} \mathrm{D}_{5}(3.2 \%)$ (total ion 量を $100 \%$ と する)

のように種々のピークが観察され, $\mathrm{C}_{1}-\mathrm{C}_{2}, \mathrm{C}_{1}-\mathrm{C}_{3}, \mathrm{C}_{1}-\mathrm{C}_{4}$ 更には $\mathrm{C}_{2}-\mathrm{C}_{3}$ 間の $\mathrm{H}$ とDの交換がおこっていることを示 している。しかしこれはすべての結合がばらばらになる ほど同時に弱まって原子の再結合がおこることではなく て, 単に多数の転位過程が各所でおこっていることであ る。一方官能基があったり分子内の分極が大きいこと, さらに転位生成するイオンが非常に安定であるため, 開 裂が非常に低い活性化エネルギーでよい場合は，他の高 い活性化エネルギーを必要とする機構を通らずに優先的 にこの転位だけがおこる。この場合 McLafferty は特殊 転位 (Specific rearrangement) ${ }^{15}$ ) と呼んだ。この転位 の型についても Biemann は以下のような分類を行なっ ている。

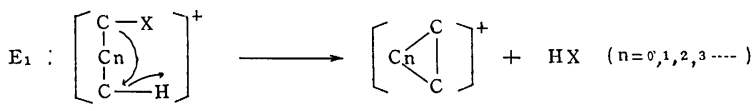

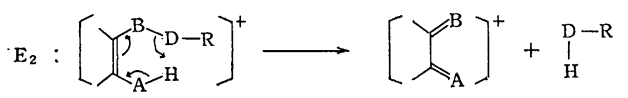

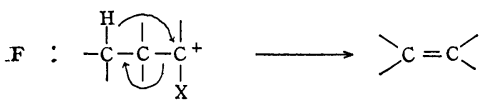

$$
\begin{aligned}
& +\underset{\substack{\frac{1}{\mathrm{H}} \\
\mathrm{C}}}{\frac{1}{\mathrm{H}}}(\mathrm{X}=\mathrm{O}, \mathrm{S}, \mathrm{N}, \mathrm{R}, \mathrm{H}
\end{aligned}
$$

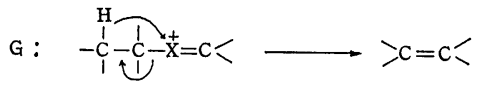

$$
\begin{aligned}
& +\quad \mathrm{HX}^{+}=\mathrm{C}^{\prime} \quad(\mathrm{X}=0, \mathrm{~S}, \mathrm{~N})
\end{aligned}
$$

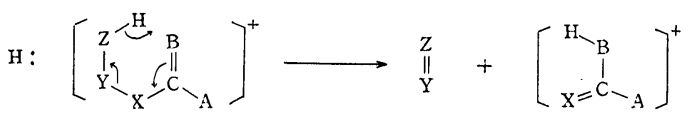

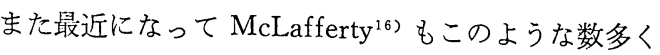
の開裂機構に対する考察をラジカルとカチオンと二つの 観点からそれぞれ分子イオンに及ぼす影響を以下のよう に定義しこれにしたがって開裂の型を 7 つに分類して いる。

ラジカル側 : 不対電子と一方の隣接する原子から一電 子 (half-arrow で表記) をとってもう一方の相隣る原 子とさらに結合をするか, ラジカルがどこか他の原子を 攻撃し転位によって新しい結合を生成する。

カチオン側：電子対 (full-arrow で表記) が正電荷を 有する方に移動し, 電荷が移動すると共に開裂がおこる か，原子もしくは原子団の攻慗によって新しい結合を生 成すると共に電荷を有する部分の結合が切れる。

$$
\begin{aligned}
& \mathrm{R}^{\prime}-\mathrm{CH}_{2}-\mathrm{OR}+\mathrm{e}^{-} \stackrel{-2 \mathrm{e}^{-}}{\longrightarrow} \mathrm{R}^{\prime}-\stackrel{\mathrm{CH}_{2}-\stackrel{\mathrm{O}}{\mathrm{O}} \mathrm{R}}{ } \\
& \longrightarrow \mathrm{R}^{\prime} \cdot+\mathrm{CH}_{2}=\stackrel{+}{\mathrm{O}} \mathrm{R}
\end{aligned}
$$

$\mathrm{R}^{\prime}-\mathrm{CH}_{2} \stackrel{+0}{\mathrm{O}}-\mathrm{R}$ $\mathrm{R}^{\prime}-\mathrm{CH}_{2} \mathrm{O} \cdot+\mathrm{R}^{+}$
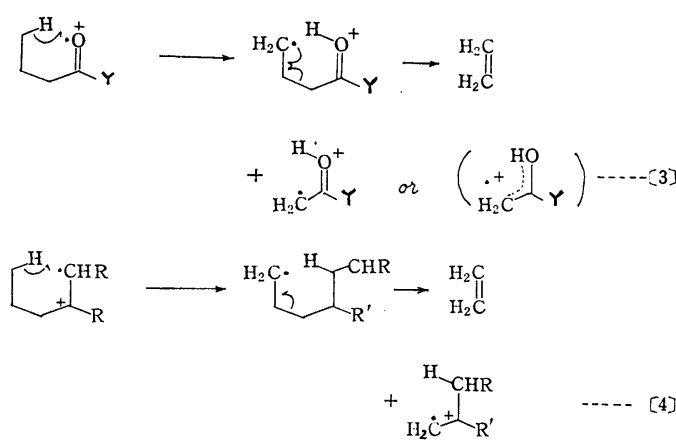<smiles>[R]C([Z17])[CH]CCC</smiles>

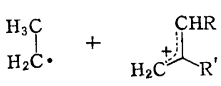<smiles>CCCC1=[C+]CCC1</smiles>

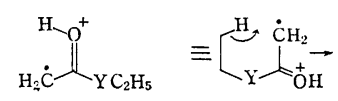<smiles>C[Al]C(C)[Hg](C)O</smiles>
(A')<smiles>C=C[C+]=C(C)[OH2+]</smiles>

(B') 


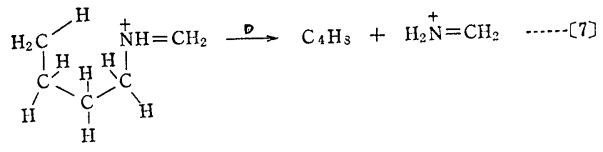

〔1〕の場合においてはラジカルの影響で不対電子が他 の一電子と新たな結合を生成することがこの開裂の driving force であり〔2】においてはカチオンが一対の結合 電子を取ってカチオンの移動を伴って開裂を進めたわけ である。〔1],〔2〕のいずれが起こりやすいかはへテロ原 子の電気陰性度が関係し，たとえばアミンの窒素はエー テルの酸素より電子を与えやすいため[2]よりむしろ[1] の反応が起こることになる。6 員環を通る〔3〕の機構 は一般に McLafferty 転位といわれ，ラジカルが水素を 引きつけ転位により新らしい結合を作る。二重結合を有 寸る化合物では〔4]のラジカルによる水素の引き抜きと 〔5】のカチオンのアリル位の開裂との競争的開裂でいず れが優先するかは最初に正に荷電した炭素についた $\mathrm{R}$, もしくは $\mathrm{R}^{\prime}$ の Inductive effect による。すなわち 2-methylalkene で $\mathrm{R}=\mathrm{H}, \mathrm{R}^{\prime}=\mathrm{Me}$ の場合は〔4]の反 応が優先し, $R^{\prime}=H, R=M e$ の場合には〔5]の反応が優 先する。〔6]の反応は連続的に水素が 2 回転位を行なう ような開裂であり,この場合 $\mathrm{A}^{\prime}$ ) の型と $\mathrm{B}^{\prime}$ ) の強度比と いうものはYの違いによって変化し $\mathrm{Y}=\mathrm{CH}_{2}$ では Bが増 加し, $\mathrm{Y}=\mathrm{O}$ では $\mathrm{B}$ が減少する。最後の[7]の開裂は最近 になって Djerassi らによる amine ${ }^{17)}$, ether, ${ }^{18)}$ thioether ${ }^{19}$ 類の重水素化体の測定から知られたものでamine お よび ether から生成する偶数の電子を有する二次イオン が再び開裂を起こすさいに転位する水素が今までと異な り，位置的特異性を失なって $\alpha, \beta, \gamma$ 抢よび $\delta$-位からそ れぞれ転位してくることがわかった。これはラジカルが 消失したためラジカル側の水素の引き抜き効果がなくな り $\mathrm{S}_{\mathrm{N}} 2$ 反応と同様の置換 (Displacement rearrang.ement）機構で開裂が進むものである。以上のように Biemann はその開裂した形で分類を試みたのに対し Mc Lafferty は開裂を促進する。カチオンとラジカルの 2 つ注目して分類を試みたことは非常に興味あること で，この法則性が確立されれば複雑な化合物の解析もそ れぞれの分類にしたがって解釈を進めればよいことにな り，きわめて明快なものになってくるものと思われる。

\section{McLafferty 転位について}

1. アルキルケトン，エステルなどで少なくとも 3 個 の炭素鎖があり，r-位に水素があるときは低エネルギー .の 6 員環状遷移状態をとりやすく，その結果水素はカル ボニル基に移動してオレフィンを離脱すると共に安定な
カチオンを生ずる。この 6 員環を通る機構については McLafferty 転位と呼ばれ，アルキルケトン，エステル 以外にも以下に示すような数多くの化合物が同樣の機構

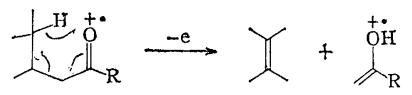

で開裂することが知られている。この転位はマススペク トルの解析を行なら上に単純開裂で見られた retro-Diels-Alder 型の開裂とならんで最も重要なものの一つで ある。以下の転位につき若干の考察をおこなってみる。

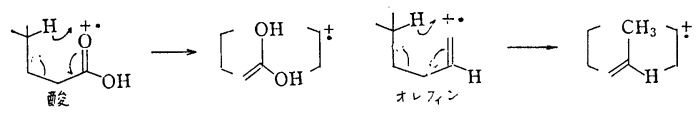

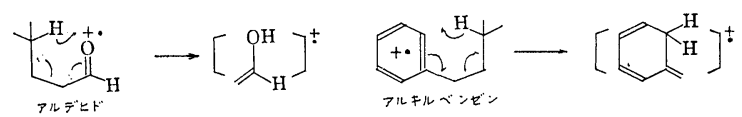

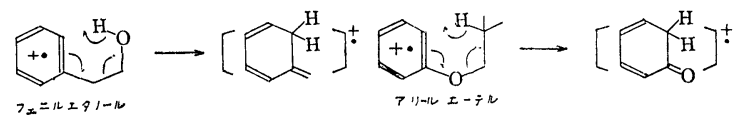

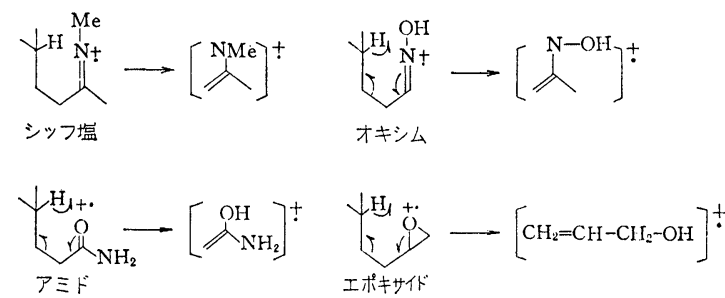

この現象を最初に発見したのは Beynon ${ }^{2 b}$ ) で, methyl-n-butyl ketone を $10 \mathrm{eV}$ から $50 \mathrm{eV}$ までエネルギ 一を変えて測定したところこのケトンは水素の転位を起 こさない低い熱電子エネルギーをあてた場合でも $\mathrm{m} / e 58$ なるフラグメントイオンを与えた。このようなイオンは
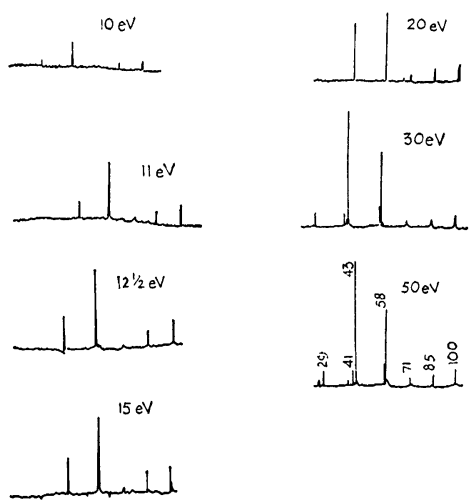

图 $5 n$-butyl ketone のマススペクトル $(50 \mathrm{eV}-10 \mathrm{eV})$ 


$$
\underset{\mathrm{O}}{\mathrm{CH}_{3}-\mathrm{C}-\mathrm{CH}_{2}-\mathrm{R}} \quad \mathrm{R}: \mathrm{CnH}_{2 \mathrm{n}+1}(\mathrm{n}=2,3,)
$$

なる一般式で表わされる化合物全てについてみることが でき，さらにカルボキシル基を $\mathrm{C}^{13}$ で標識した酪酸のマ ススペクトルにも $\mathrm{C}^{13}$ をふく相当するイオンのあらわ れることが確認された ${ }^{20)}$ 。また di-tert-butyl ketone (1) においては

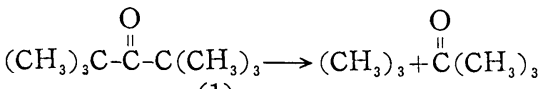

なる開裂のみを行ない，r-位に水素をもつ di-isobutyl ketone（2）になるとはじめて

$$
\left(\mathrm{CH}_{3}\right)_{2} \cdot \mathrm{CHCH}_{2}-\stackrel{\mathrm{O}}{\mathrm{C}}-\mathrm{CH}_{2} \mathrm{CH}\left(\mathrm{CH}_{3}\right)_{2}
$$

(2) $\mathrm{OH}$

$\longrightarrow \mathrm{C}_{2} \mathrm{H}_{6}+{ }^{+} \mathrm{CH}_{2}=\stackrel{\mathrm{C}}{\mathrm{C}}-\mathrm{CH}_{2} \mathrm{CH}\left(\mathrm{CH}_{3}\right)_{2}$

の開裂が見られることも同じ頃に観察された。 McLafferty 転位はこのような研究的背景をもとにして提出さ れたものである。この転位によって生成したイオンの形 は，(a)のケト形および (b) のエノール形の 2 つが考え

$$
\mathrm{CH}_{3}-\stackrel{+}{\mathrm{O}}
$$

(a)

(b)<smiles>[R]C(=C)[OH2+]</smiles>

られるがイオンの出現電圧を測定した結果 (b) のエノー ル形をとっていることが明らかにされた ${ }^{8 \mathrm{e})}$ 。最終的に は butyric acid ester とその重水素化誘導体のスペク トルを検討することによって $r$-位の水素が選択的に転 位することが明らかにされている21)。
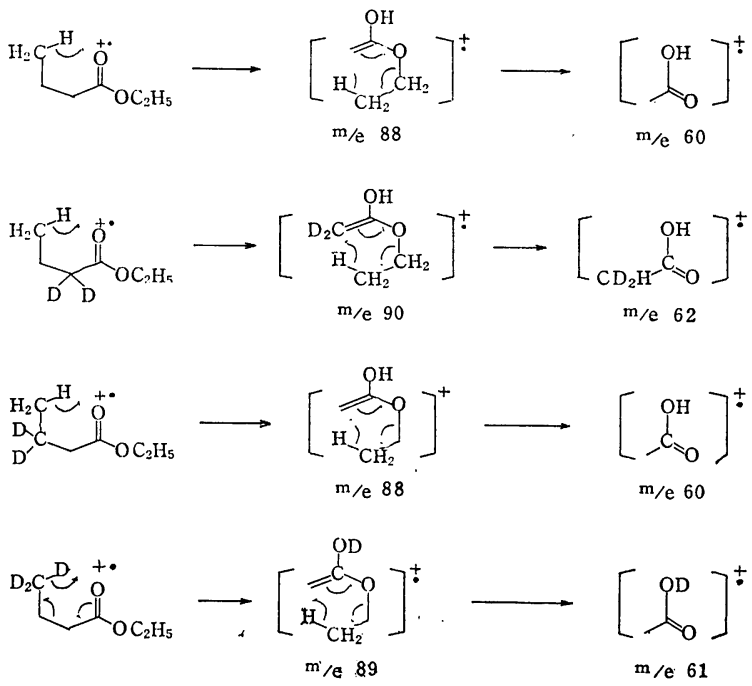

McLafferty 転位は鎖状の化合物ばかりでなく環 状のも。 のだも $r$-位に水素があれば起きることが 2-ethylcyclo pentanone（3）のマススペクトルによって知られてい $3^{\text {a a)。 }}$

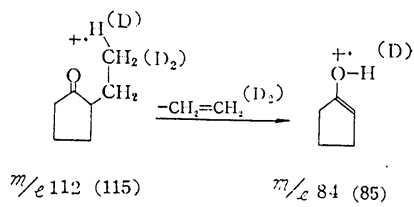

(3)

なおこの開裂について研究が進み，数多くの報告がな されるようになるとカルボニルを有する部分が正電荷を 有するばかりでなく，中性分子として離脱していった部 分にも電㐿の存在することが報告された ${ }^{22) 。}$

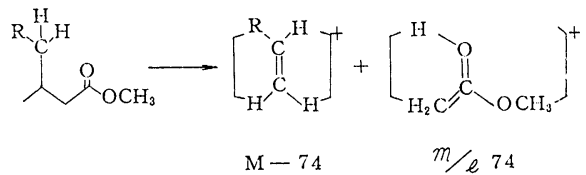

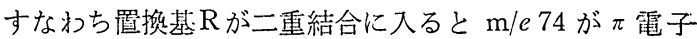
で安定化されると同様に M-74 も電荷を有するように なる。またアルカロイド Vobasin (4) ${ }^{23)}$ にみられるご とく C-5, C-6 閒の結合が切れ C-5 位に 正電荷が残 り，これがNの不対電子と共鳴安定化し（c）を生じつい で McLafferty 転位をおこして（d）イオンが生成する という例もある。

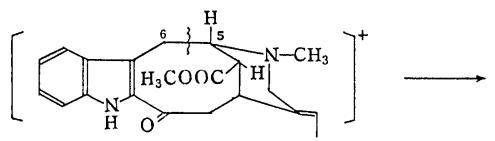

(4)

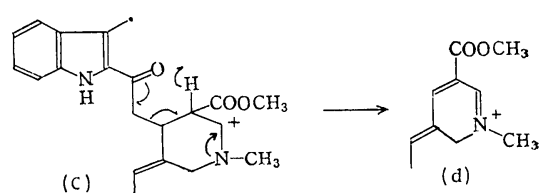

2. McLafferty 転位における立体的要·素 いま まで述べた McLafferty 転位をおこなう化合物はいずれ も鎖状もしくは長い側鎖をもつ環状化合物であり，酸素 原子に $r$-位の水素が近ずきうるため容易に 6 員㻴 遷移 状態をとり得るが，固定された分子構造をもつ化合物た とえばステロイド，テルペン等においてはたとえ 6 員環

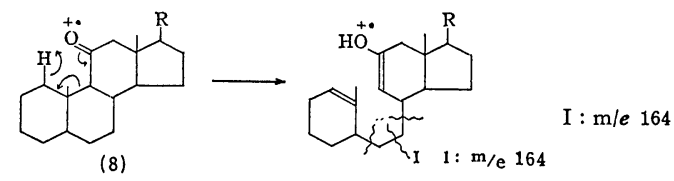


を形成しうる位置にカルボニル基と $r$ 水素が存在しても 環状遷移状態に関与する原子間の距離, 環状体が生成し た場合の平面性等が考慮されなければならない。すなわ ち以前はステロイド等の McLafferty 転位はかならずし も立体的な要因を考えずにその機構を適用してきた しかしながら

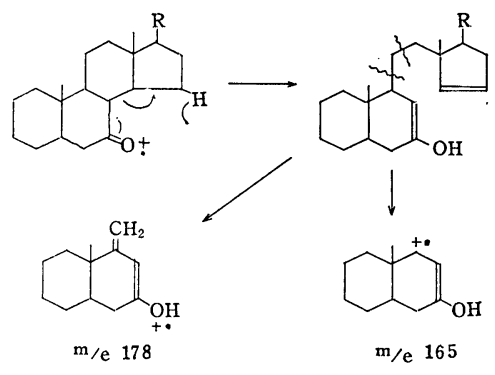

最近になってDjerassi らは固定された化合物における この機構を検討するために各種のステロイドケトンの重 水素化体を合成しそのマススペクトルから McLafferty 転位が起きる場合の立体的な問題について考察している ので，それについてのべてみたい。

3. McLafferty 転位に及ぼす同位体効果 有機 化合物の必要な位置を重水素でラベルすることは開裂機 構および特別の転位機構を洞察するために非常に有用な 方法である。置換基の変化もしくは新らたな置換基の導 入もおこなわれるが往々にして全体の開裂様式を全く変 化させてしまうことがあるのに反し, 重水素でラベルす る方法は開裂様式に何等の変化ももたらさず，単に同位 体効果它考慮すればよい点きわめて便利である。同位体 効果とはたとえば重水素化した炭化水素においては水素

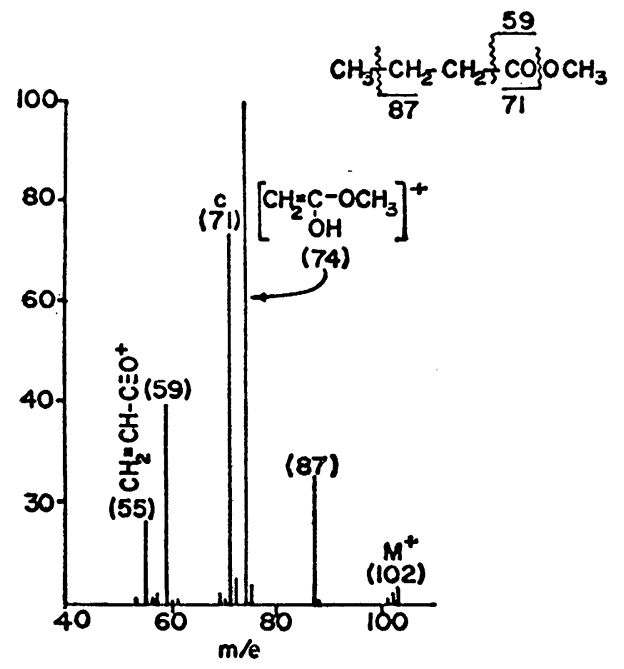

図 6 methyl-butyrate (5) のマススペクトル
より重水素のほうが離脱しにくく，環状ケトンやシクロ ヘキサノールから脱水が起きる場合に重水素と水素との とり込みに差がみられるといった現象をいう。したがっ てMcLafferty 転位を考えるさいにもこの効果を考慮し なければならない。 methyl-butyrate (5)は McLafferty 転位を起こし $\mathrm{m} / e 74$ なるピークを与えるが，このもの と合成によって得た $r-\mathrm{d}_{1}, r-\mathrm{d}_{2}$ 体のマススペクトルか ら同位体効果 (I.E.) を求めるとつぎのようになる ${ }^{25)} 。$

表 1 methyl- $\gamma-\mathrm{d}_{1}$-butytate(6)-および methyl- $\gamma-\mathrm{d}_{2}$ butytate (7) の同位体効果

\begin{tabular}{|c|c|c|c|c|c|c|}
\hline & a & \multicolumn{2}{|c|}{ b } & c & d & I.E. \\
\hline \multirow{2}{*}{ (6) $\begin{array}{l}\mathrm{m} / e 74 \\
\mathrm{~m} / e 75\end{array}$} & 100 & \multirow{2}{*}{\multicolumn{2}{|c|}{$\begin{array}{c}100 \\
42.3\end{array}$}} & 96.6 & 69.6 & 30.4 \\
\hline & 46.2 & & & 42.3 & 30.4 & $\overline{34.8}=$ \\
\hline \multicolumn{7}{|c|}{ 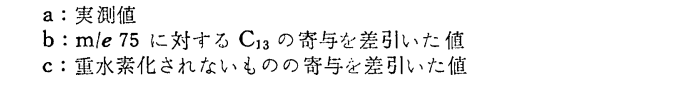 } \\
\hline & $\mathrm{a}$ & b & $c$ & d & e & I.E. \\
\hline \multirow{2}{*}{ (7) $\begin{array}{l}\mathrm{m} / e 74 \\
\mathrm{~m} / e 75\end{array}$} & 67.0 & 57.4 & 57.4 & 54.6 & 36.1 & 31.95 \\
\hline & 100 & 100 & 97.8 & 96.4 & 63.9 & 36.1 \\
\hline
\end{tabular}

a : 实测值

$\mathrm{b}: \mathrm{m} / e 74$ に対する $\mathrm{C}_{13}$ の笴年落差引いた值

c : mel 75 に対寸る $\mathrm{C}_{13}$ 寄与在差引いた值

$\mathrm{d}$ : 完全に重水菜化されないものの寄与去差引いた值

表 1 から明らかなように重水素が入った場合にその I. E. はほぼ 0.88 となり以下にのべる McLafferty 転位 を考えるさいにもこれを適用することになる。

\section{4. ステロイドケトンにおける McLafferty 転 位} 前にも述べたように 11-ケトステロイド (8) が $\mathrm{m} / e$ 164 のピークを示し同様の機構が 1,7 ，または 15-ケト ステロイド体においても報告されている24)。しかし 11ケトステロイドの場合 $\mathrm{C}-1$ 位を重水素で置換したもの を測定してもその位置から重水素の移動は全くみられ す，表に示すようにC-1位以外の炭素からの移動が観察 され（表 2)，きわめて複雑な転位のおこっているのが わかる ${ }^{26,29) 。 ~}$

表 2 イオン $\mathrm{m} / e 164$ の生成に寄与する水素のオリジン

\begin{tabular}{|c|c|c|c|}
\hline & $\begin{array}{l}\text { Dが m/e } 164 \text { に移動 } \\
\text { する割合 }\end{array}$ & & $\begin{array}{l}\text { Dが m/e } 164 \text { がら } \\
\text { 離れる割合 }\end{array}$ \\
\hline $\mathrm{C}-1$ & 0.0 & C-8 & 0.83 \\
\hline $\mathrm{C}-2$ & 0.15 & C-9 & $0.21 \sim 0.27$ \\
\hline $\mathrm{C}-3$ & 0.10 . & $\mathrm{C}-12(\alpha)$ & 0.15 \\
\hline$C-4$ & 0.56 & $C-12(\beta)$ & 0.01 \\
\hline $\mathrm{C}-5$ & $0.24 \sim 0.30$ & $\mathrm{C}-17$ & 0.0 \\
\hline $\mathrm{C}-6$ & $0.16 \sim 0.44$ & & \\
\hline 計 & $1.21 \sim 1.55$ & 計 & $1.20 \sim 1.26$ \\
\hline
\end{tabular}

したがってこの場合は McLafferty 転位をおこしうる 位置に水素が存在はするが，この機構を通るものではな 
くC-8 位なり C-4 位なりの水素がつぎのように移動す るものと考えられる。
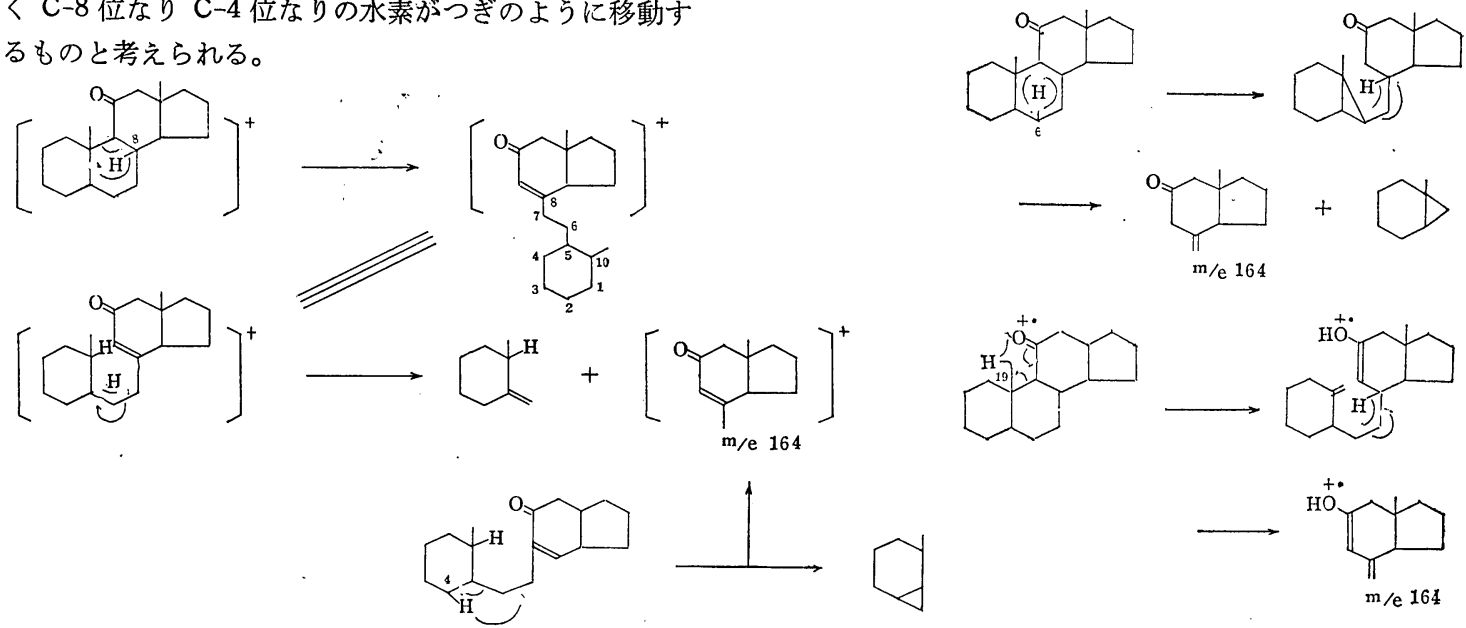

同栐に C-5, C-6, C-19 位の水素の移動はつぎのように

考えられよう。
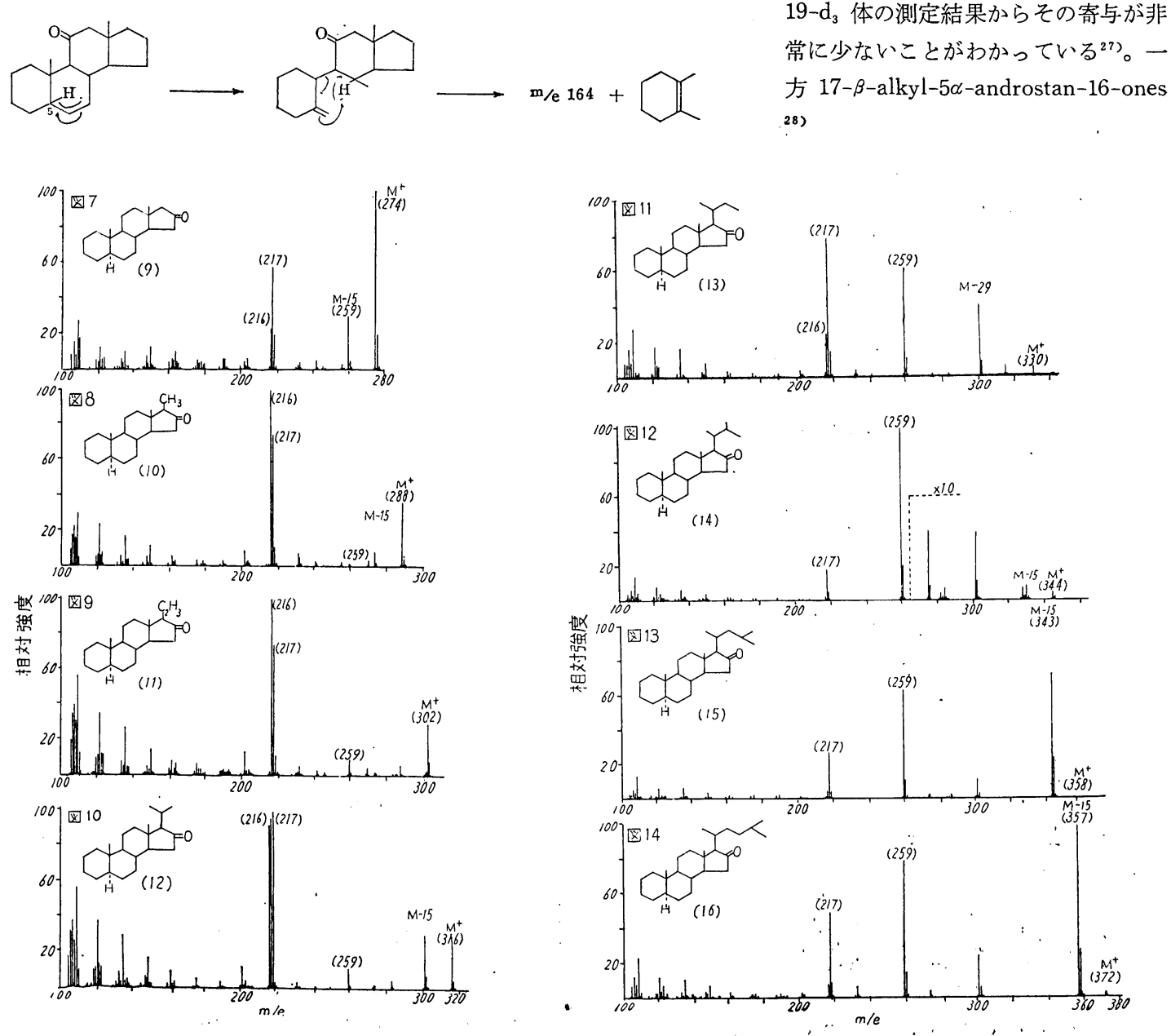


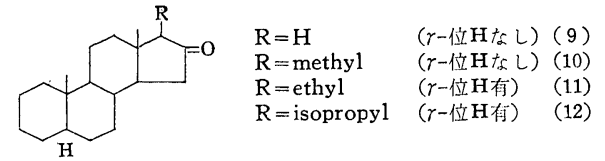

れおいても McLafferty 転位を経て生じたと思われる イオンが $\mathrm{m} / e 259$ にあらわれる(図 7,8,9,10)。

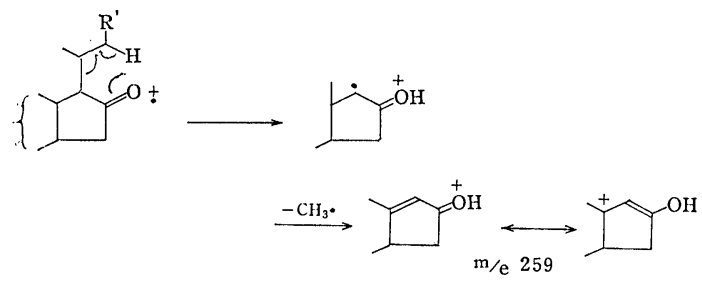

このとき $\mathrm{R} か ゙$ 水素もしくはメチル基の場合は当然ながら -m/e 259 は非常に強度が小さい。（わずかにこのピーク がみられることは他にもこの質量数を与える機構がある ことを意味している。）しかしRがエチルとなればしだ い汇その強度を增し， $r$ 位の水素の $60 \%$ が McLafferty 転位を起こすようになりさらにRがイソプロピルのとき 《その $89 \%$ がこの転位を起こしていることがそれぞれ の重水素化体で理解される。<smiles>[R]C([AlH2])C1C(=O)CC(C)C1(C)CC</smiles>

$\mathrm{R}:$ ethyl
$\mathrm{R}:$ isopropyl
$\mathrm{R}$ : isobuthyl (14)
$\mathrm{R}:$ 3-methyl butyl(16)

なお $\mathrm{R} か ゙ 13,14,15,16$ のようになれば $\mathrm{m} / e 259$ の強度 岄いちじるしく増加し McLafferty 転位が圧倒的に他 の開裂に優先して起っていることがわかる。(図11,12， 13，14）。このとき転位する水素は 表 3 から明らかなよ うに $21,21,21-\mathrm{d}_{3}$ 体ではその $3 \%$ が $\mathrm{m} / \mathrm{e} 260$ に移り， $15,15,21,21,21-\mathrm{d}_{5}$ 体でやはり $3 \% \mathrm{~m} / e 261$ が $\mathrm{m} / e 262$ に移動する。

一方 $21,21,21,22,22,23,23,23-\mathrm{d}_{8}$ 体ではほとんど全 てのピークが $\mathrm{m} / e 260$ に移動することから C-23 位の水 素の転位を無視できるとすれば $\mathrm{m} / \mathrm{e} 259$ は完全に Mc-
Lafferty 転位機構を通っており，その場合 C-22 位から の水菜の転位が $97 \%, \mathrm{C}-21$ 位の水素の転位が 3\% 位の 割合で関与していることになる。

さてこのように11-ケトステロイドにおいては $\mathrm{Mc}$ Lafferty 転位がみられず，16 ケトステロイドにおいて はじめてそれがみられるということは，その転位の有無 を決定する何らかの要因があるべきでこれに関して Djerassi らは $\gamma$-位の水素原子とこれを受け取る酸素原子 との間の原子間距離に注目した ${ }^{28,29) 。 ~}$

Dreiding model によれば各種ステロイドケトンにお ける $\mathrm{H} \longleftrightarrow \mathrm{O}$ 間の原子間距離はそれぞれ以下のように なる。

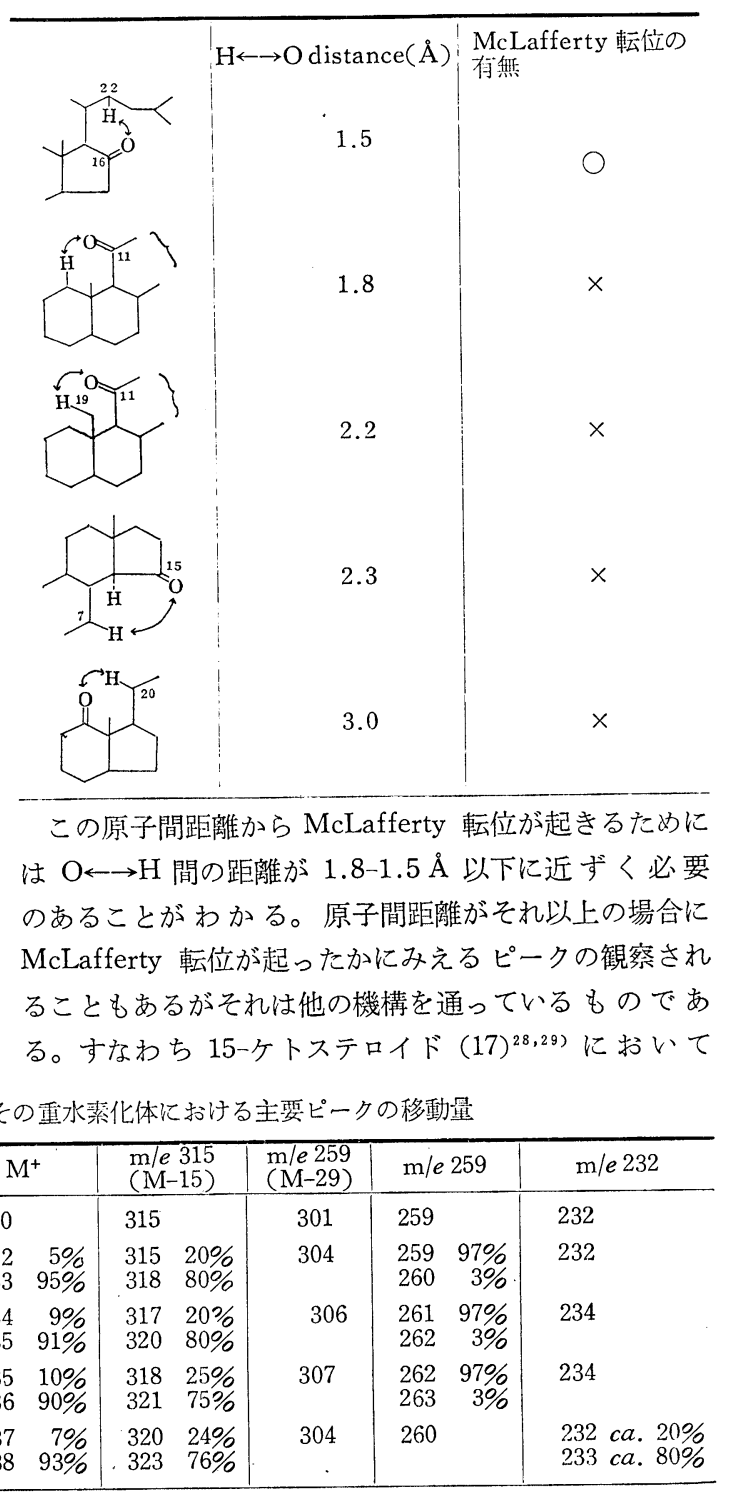




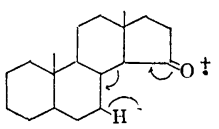

(17)
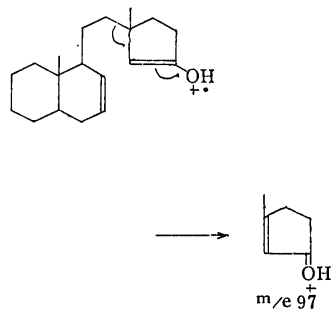

$\mathrm{m} / \mathrm{e} 97$ の質量数を有するピークがかなりの強度で表わ れているが, $7 \beta-\mathrm{d}_{1}, 7.7-\mathrm{d}_{2}-15$ ケトステロイド体のマス スペクトルを測定しても $\mathrm{m} / e 97$ が $\mathrm{m} / e 98$ にシフトす るということはないからこの $\mathrm{m} / e 97$ の質量数を有する ものは (e)または (f) に相当するイオンであろ5 ${ }^{30}$ )。<smiles>O=C1CC[C@H]2CCC34CCCCC3CCCC124</smiles>

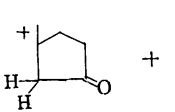<smiles>CCC1CCCC2CCCCC12</smiles>

(e)

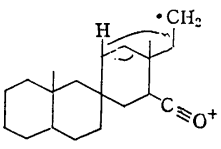<smiles>CCCCCC</smiles><smiles>CCCCC1(C=C=[O+])CCC2CCCCC2C1</smiles><smiles>CCC(C)C=[O+]</smiles>

また C-12 ケトステロイド $(18)^{31)}$ とおいては

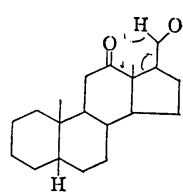

(18)
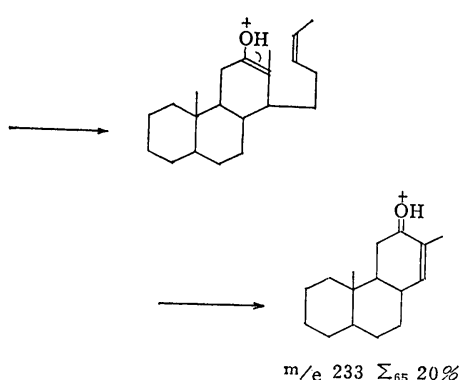

$\mathrm{m} / \mathrm{e} 233$ の質量数を有するピークがベースピークとして 表わ机ており，このピークは C-20 の重水素化体におい てはその $90 \%$ が $\mathrm{m} / e 234$ に移動していることから McLafferty 転位がおこったものと考えたいところである が, Dreiding model からの原子間距離の測定では $3 \AA$ のへだたりがあり他の機構を考えねばならない。すなわ ちカルボニル基のないステロイドにおいてはまず $\mathrm{D}$ 環が （g）のように開裂し，ついで任意の場所から水素を引き 抜いてゆく機構が知られているが，12-ケトステロイド<smiles>CC1CCC2C3CCC3CC[C@]12C</smiles>
の場合にも正電荷がカルボニル基に局在化 したままで $\mathrm{C}_{13}-\mathrm{C}_{17}$ 結合が homolytic に

(g) 切断され trans-hydrindane 形のひずみの
かかった状態から開放され，( $\left.g^{\prime}\right)$ のような中間体を生 成し続いてこのラジカルに対して C-20 位の水素もしく は C-16 位の水素が転位してゆくとすれば一応の説明が 可能である。

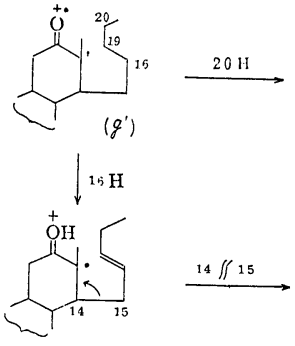

(i)

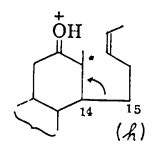

$\mid 14 \int / 15$<smiles>CC1=CC2CCC2CC1[OH+]</smiles>

(j) $\mathrm{m} / \mathrm{e} 233$
このさい C-20 と C-16 の水素の転位する割合に差がす られるのはステロイドのC環が椅子形の場 合には（ $g^{\prime} ）$ で C-20 の水素が $1.7 \AA$ まで近ずき得るのに対し C-16 の水素は $3.8 \AA$ までしか近ずき得ないことによろもので あろう。またC 環が反転して C-20 位の水素はカルボニ ル基に対し，任務の距離をとり得るようになっても C16 位の水素はたかだか $1.5 \AA$ までしか近ずき得ないた めにこのような差がでるとされている。この考え方にし. たがうと正電荷の中心がどこにあるかによってマススべ クトルは変化し，比較的ひずみの少ない場合でも同様の 変化がみられるはずである。事実 hecogenin (19) に打 いてはスピロケタール部の酸素に正笔荷が保持されるた めに $\mathrm{m} / e 249(233+\mathrm{OH})$ にはピークはみられず $3 \beta-$ acetoxy-12-oxoursane（20）に拈いてはひずみの少ない.<smiles>CC1CCC2(CC1)OC1CC3C4CCC5CC(O)CCC5(CC4C3C1)C2C(=O)O</smiles>

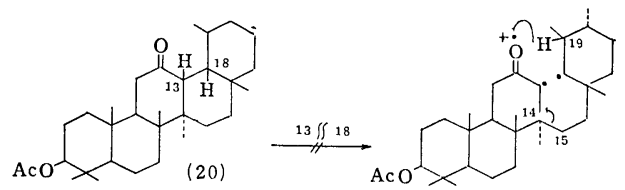

(20)<smiles>CC(C)=O</smiles>

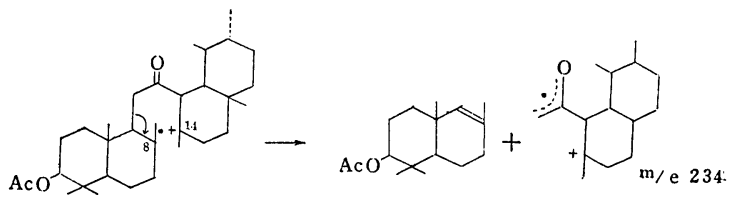


$\mathrm{C}_{13}-\mathrm{C}_{18}$ 間で切れることなく $\mathrm{C}_{8}-\mathrm{C}_{14}$ 間で切れた $\mathrm{m} / e 234$ を与える。さらに 12 位にカルボニル基のない場合 $\mathrm{C}_{13}$ 位 にある核間メチル基は C-21のメチル基より離脱しやす いのは当然であるがカルボニル基が C-12 位にあると最 初に $\mathrm{C}_{13}-\mathrm{C}_{17}$ 位が切れこのあとのメチル基の離脱は $\mathrm{C}$ 21 位から抗こることが重水素化体の测定によってわか っている。これは $\mathrm{C}_{13}$ 位のメチル基が放れると不安定な biradical を生ずるため前者が優先するわけである。こ のような実験によって McLafferty 転位が起きる場 合

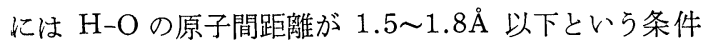
を必要とすることがわかった。ただし 16-ケトステロイ ドにおいて側鎖が違ってくると共に McLafferty 転位に よって生成したピークの強度にかなりの変化があること が図 7 14で観察される。またこのような置換基の性質 の相違による水素移動の難易はtert $-\mathrm{H}>$ sec $-\mathrm{H}>$ primHの順である。たとえば 5 $\alpha$-pregnan-16-one (11), 20methyl-5 $\alpha$-pregnan-16-one（12）は $\gamma$-位に水素を 3 個 もつにもかかわらず全体のイオン量からみてその生成量 はさほど大きくない（図 9,10）。しかし 20-ethyl-5 $\alpha$ pregnan-16-one (13) のように二級になると m/e 259 の 生成量は漸次増大し, McLafferty 転位が非常に起こり やすくなってきていることがわかる（図 11）。さらに 20-isopropyl-5 $\alpha$-pregnan-16-one（14）になると $\gamma$-位 に水素が 1 個しかなくとも $\mathrm{m} / e 259$ はベースピークと なり McLafferty 転位が全体の 開裂機。構を支配する程 になる（図 12）。この化合物に抒いては他の16-ケト体

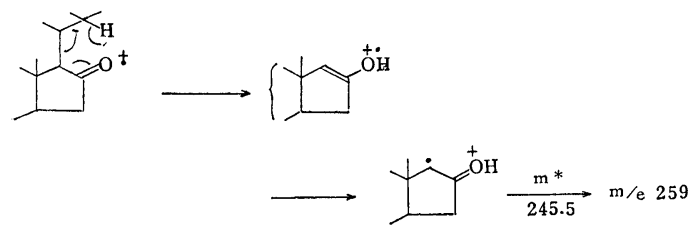

飞はほとんどみられなかった。 $\mathrm{m} / e 274$ がみられ続いて メチルラジカルが離脱して $\mathrm{m} / \mathrm{e} 259$ を与える過程が, メタステーブル・ピークの存在から確認された。以上の ことから Mc Lafferty 転位を支配する第二の因子とし て置換基の一級，二級，三級による差があげられること がわかろう。さらに第三の要素としては, 化合物 (13), (14), (15), (16) のように $\mathrm{C}_{18}$ メチル基と C-17 位の間 が立体的に混み合ってくると， $\mathrm{C}_{17}-\mathrm{C}_{20}$ の結合の自由回 転が阻害され，それが McLafferty 転位に対し影響を 与える可能性が出てくる。そこで立体障害のないような モデル化合物 2-(1-methylpropyl)cyclopentanone (21) とその重水素化体 (22)，および 2-ethylcyclopentanone (23) を合成し，そのマススペクトルが測定された ${ }^{322}$ 。

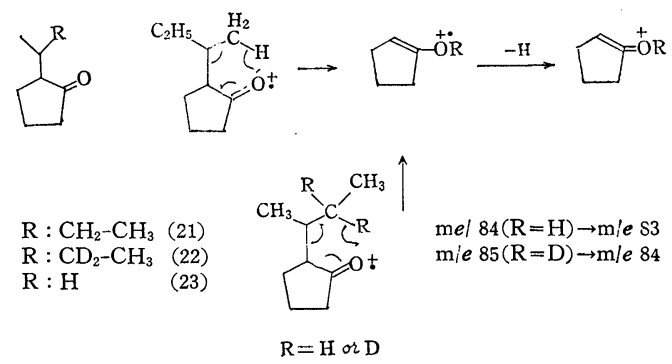

これを解析すると $\mathrm{m} / e 85$ (78\%)， m/e $84(22 \%)$ とな り 16-ケトステロイドにおける C-22 位から $97 \%$, C-21 位から $3 \%$ の值と違ってきており，この分だけ立体的な 影響がきいてきていることになり，立体障害も McLafferty 転位の第三の要素として考える必要のあることが わかる。

5. その他の McLafferty 転位に関する研究こ れまでのべたようにステロイドケトンを中心とした Mc Lafferty 転位については，くわしくその研究がなされ， しだい㲹その機構および開裂の生起を支配する要素等が 明らかにされつつある。一方ケトステロイド以外にもこ の転位機構について考察がなされている。すなわちアリ ールエーテル等において前にも記したように

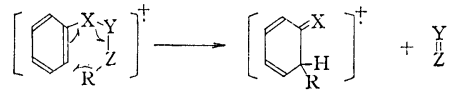

$$
\begin{aligned}
& \mathrm{x}=\mathrm{CH}_{2}, \mathrm{O}, \mathrm{S}, \mathrm{NH}
\end{aligned}
$$

のような転位が $\mathrm{R}=\mathrm{H}$ の場合には非常に多く起こるこ とが知られており，そこで $\mathrm{R}=\mathrm{CH}_{3}$ の場合にもこれと 同様の転位がみられるかどらかが調べられた ${ }^{33)}$ 。それに よると重水素化体のマススペクトルから以下の機構を通 って生成する $\mathrm{m} / \mathrm{e} 109$ は全く見られなかった。

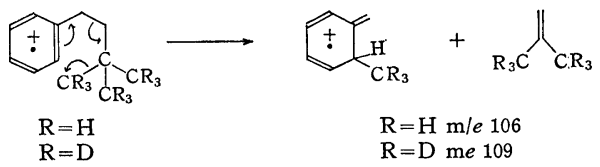

これに類似した一連の化合物においてもそれぞれメチル 基の転位は全く見られない。
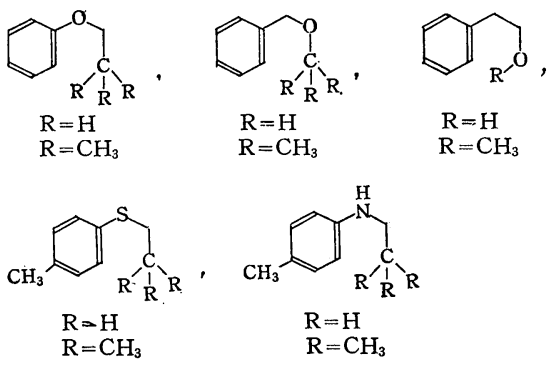


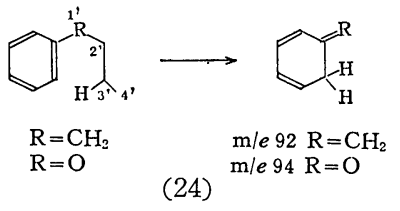

またつぎの化合物（24）の各位置を重水素化した誘導体 のマススペクトルを测定するとアルキルベンゼンや $2^{\prime}, 3^{\prime}$ $4^{\prime}$ 位に酸素のある場合には，優先的に McLafferty 転 位がみられるが，I' 位に酸素のあるものにおいては

\begin{tabular}{|c|c|c|c|c|}
\hline & $\alpha-\mathrm{d}_{2}$ & $\beta-\mathrm{d}_{2}$ & $r-d_{2}$ & $\delta-d_{3}$ \\
\hline 正水素の移動率\% & 15 & 25 & 29 & 16 \\
\hline
\end{tabular}

となり, 水素の転位はその特異性を失って正常の $\mathrm{Mc}$ Lafferty 転位と称し得るものは 25\%しか起こっていな いことがわかっだ4。すなわちこのような場合は phenol イオン・ラジカルの共鳴安定化の笴与が大きくきいてき ているものであり, McLafferty が分類した 7) 型の機 構にしたがって開裂するようになるであろう。

このように研究が進むにつれて当然 McLafferty 転位 が起こると思われていたものにも例外がみられるように なり，なお一層の研究が望まれるが McLafferty がの ベたようにカチオン, ラジカルの局在化した時の状態が つぎの転位を起こさせる driving force となるとする ことは非常に良い考えであって Djerassi らも McLafferty 転位が起きるのは, 奇数電子イオン (ion-radical) の場合にしばしばみられ，偶数電子イオンの場合にはそ れがみられなくなっているといっている ${ }^{35}$ がこれらにつ いてはまた機会があったらのべてみたいと思う。

謝辞 原稿作製にあたって日下継子嫃のお手数をわづ らわした。あつくお礼申し上げます。 (昭和 41 年 6 月 23 日受理)

\section{文献}

1) C. Djerassi, R.H. Shapiro, M. Vandewalle, J. Am. Chem. Soc. 874892 (1965)

2a) J.H. Beynon; "Mass Spectrometry and its. Application to Organic Chemistiy" Elsevier, Amsterdam 1960

b) J.H. Beynon [2a] p. 356

3) R. Ryhage, E. Stenhagen, J. Lipid Res. I 361 (1960)

4) R. Ryhage, E. Stenhagen, in F.W. McLafferty, "Mass Spectrometry of Organic Ions." Academic press, New York 1963. p. 399-452

5) H.M. Grubb, S. Meyerson in [4], p. 453-528

6) F.W. Mc Lafferty, Analyt. Chem.28 306 (1956)

7) K. Biemann,"Mass Spectrometry Organic Chemical Applications" McGraw. Hill. New York. 1962 8a) K. Biemann in [7] p. 74

b) K. Biemann in [7] p. 47

c) in [7] p. 48, (d) in [7] p. 76, [e] in [7] p.120

9a) H. Budzikiewicz, C. Djerassi, D.H. Williams. "Interpretation of Mass Spectra of Organic Compounds" Holden-Day, San Francisco, 1964

b) "Structure Elucidation of Natural Products by Mass Spectrometry" Vol. I, Alkaloids. Vol. II, Steroids, Terpenoids, Sugars, miscellaneous classes. Holden-Day, San Francisco. 1964

10) G. Spiteller, M. Spitteller-Friendmann, Angew. Chem. Internat. Edit. 4383 (1965)

11) M.U. Ardenne, K. Steinfelder, R. Tümmler, Angew. Chem. 73136 (1961)

12) R.T. Alpin, H. Budzikiewicz, C. Djerassi, $J$. Am. Chem. Soc. 873180 (1965)

13) H.M. Rosenstock M. Krauss, "Quasi-Equilibrium Theory of Mass Spectra" in [9]

14) M.V. Gurév, Dokl. Akad. Nauk. USSR. 136: 856 (1961)

15) F.W. McLafferty, Analyt. Chem. 3182 (1956)

16) F.W. McLafferty, Chem. Comm. 78 (1966)

17) C. Djerassi, C. Fenselau, J. Am. Chem.Soc. 875752 (1965)

18) C. Djerassi, C. Fenselau, J. Am. Chem. Soc. 875747 (1965)

19) S. Sample, C. Djerassi, J. Am. Chem. Soc. 88 1937 (1966)

20) G.P. Hap, D.W. Stewart, J. Am. Chem. Soc. 744404 (1952)

21) N.D. Nguyer, R. Ryhage, S.S. Stenhagen, E. Stenhagen, Arkiv. Kemi. 18393 (1961)

22) G. Spiteller, M. Spiteller-Friedmann, Monatsh. 95257 (1964)

23) V. Renner, D.A. Prins, A.L. Burtingame, K. Biemann, Helv. Chim. Acta. 462186 (1963)

24) H. Budzikiewicz, C. Djerassi, J. Am. Chem. Soc. 841430 (1962)

25) D.H. Williams, H. Budzikiewicz, C. Djerassi, J. Am. Chem. Soc. 86284 (1.964)

26) D.H. Williams, J.M. Wilson, H. Budiikiewiez, C. Djerassi, J. Am. Chem. Soc. 852091 (1963)

27) D.H. Williams, C. Djerassi, Steroids 3259 (1964)

28) C. Breard, J.M. Wilson, H. Budzikiewicz, C. Djerassi, J. Am. Chem. Soc. 86269 (1964)

29) C. Djerassi, International Symposium. Kyoto. 1964

30) C. Djerassi, G. Von Mutzrbacher, J. Fajkos. D.H. Williams H. Büdzikiewicz, J. Am. Chem. Soc. 87817 (1965)

31) C. Djerassi, L. Tökés, J. Am. Chem. Soc. 88 536 (1966)

32) H. Fritz, H. Budzikiewicz, C. Djerassi, Chem. Ber. 9935 (1966)

33) M. Fisher, C. Djerassi, Chem. Ber. 99750 (1966)

34) J.K. McLeod, C. Djerassi, J. Am. Chem. Soc. 881840 (1966)

35) C. Djerassi, M. Fischer, J.B. Thomson, Chem. Comm. 12 (1966) 